\title{
The Effectiveness of Herbal Antibacterial Formulations Against Mastitis-Causing Bacteria in Dairy Cattle
}

\author{
Sari Suryanah* and Syifa Nurjannah \\ Faculty of Agriculture, Insan Cendekia Mandiri University, Bandung, Indonesia \\ *Corresponding author email: hikmah99@yahoo.co.id
}

\begin{abstract}
This study aimed to determine the effectiveness of antibacterial formulations derived from herbal plants against mastitis-causing bacteria in dairy cattle. Herbal extracts composed of betel leaves extract, kecombrang flower extract, and turmeric extract were tested against Staphylococcus aureus, Streptococcus agalactiae, and Escherichia coli. The research was carried out in a Completely Randomized Design (CRD) using ten treatments and four replications at the Laboratory of Research and Testing, Faculty of Animal Husbandry, Padjadjaran University. The results showed that herbal antibacterial formulations could inhibit the growth of Staphylococcus aureus, Streptococcus agalactiae, and Escherichia coli bacteria. The most inhibitory power was obtained from P8 treatment ( $50 \%$ betel leaves $+50 \%$ kecombrang flower $+50 \%$ turmeric) categorized in "strong inhibition." The percentage of antibacterial inhibition of P8 formulation compared to chloramphenicol was 32\% against Staphylococcus aureus, 33\% against Streptococcus agalactiae, and 31\% against Escherichia coli. Conclusively, the best herbal antibacterial formulation was a combination of $50 \%$ betel leaves extract, $50 \%$ kecombrang flower extract, and 50\% turmeric extract.
\end{abstract}

Keywords: mastitis, betel leaves extract, kecombrang flower extract, turmeric extract, herbal antibacterial

Abstrak. Penelitian ini bertujuan untuk mengetahui efektivitas formulasi antibakteri yang berasal dari tanaman herbal terhadap bakteri penyebab mastitis pada sapi perah. Ekstrak herbal yang digunakan terdiri atas ekstrak daun sirih, ekstrak bunga kecombrang, dan ekstrak kunyit. Bakteri uji yang digunakan adalah Staphylococcus aureus, Streptococcus agalactiae, dan Escherichia coli. Penelitian dilaksanakan di Laboratorium Riset dan Pengujian, Fakultas Peternakan, Universitas Padjadjaran. Penelitian menggunakan Rancangan Acak Lengkap (RAL), terdiri atas 10 perlakuan dan 4 ulangan. Hasil penelitian menunjukkan bahwa formulasi antibakteri herbal dapat menghambat pertumbuhan bakteri Staphylococcus aureus, Streptococcus agalactiae, dan Escherichia coli. Daya hambat terbesar diperoleh pada perlakuan P8 (kombinasi ekstrak daun sirih 50\%, ekstrak bunga kecombrang $50 \%$, dan ekstrak kunyit 50\%) dengan daya hambat kategori kuat. Persentase daya hambat antibakteri formulasi P8 dibandingkan dengan chloramphenicol adalah 32\% terhadap bakteri Staphylococcus aureus, 33\% terhadap bakteri Streptococcus agalactiae, dan 31\% terhadap bakteri Escherichia coli. Dari hasil tersebut dapat disimpulkan bahwa formulasi antibakteri herbal terbaik adalah pada kombinasi ekstrak daun sirih 50\%, ekstrak bunga kecombrang 50\%, dan ekstrak kunyit 50\%.

Kata Kunci: mastitis, ekstrak daun sirih, ekstrak bunga kecombrang, ekstrak kunyit, antibakteri herbal

\section{Introduction}

Mastitis is a disease that often affects the clinical and sub-clinical conditions of dairy cattle. Mastitis is responsible for the declining milk production and milk quality and the acceleration of dairy cattle culling that brings major impacts on the income and acceptance of farmers (Seegers et al., 2003).

There are many reports of mastitis cases in Indonesia, including clinical and subclinical mastitis (Syamsi et al., 2019). While farmers are generally familiar with clinical mastitis from its recognizable visual symptoms, subclinical mastitis is not directly recognized due to invisible symptoms (Sutarti et al., 2003). Wahyuni et al. (2006) reported the prevalence of subclinical mastitis in dairy cattle across cities in Indonesia, including $76 \%$ in Bogor (West Java), 91\% in Boyolali (Central Java), and $81 \%$ in Malang (East Java). Mastitis is usually caused by bacterial contamination, such as Staphylococcus aureus, Streptococcus agalactiae, and Escherichia coli (Pisestyani et al., 2017).

Farmers usually treat mastitis cows using antibiotics. Unfortunately, the antibiotic residue 
is released through the milk and can harm human health (Sachi et al., 2019) by causing antibiotic resistance, allergic reactions, carcinogenicity, and disturbances in the normal intestinal environment (Beyene, 2016). Therefore, we need alternative antibacterial products derived from herbal plant extracts to provide safe treatments, readily available, inexpensively manufactured, and nonantimicrobial resistant (Pasca et al., 2017).

Betel leaves (Piper betle L.), kecombrang flower, and turmeric are herbal plants feasible for antibacterial agents to inhibit the growth of pathogenic bacteria. Betel leaf contains essential oils that are very effective as an antimicrobial agent (Caburian and Osi, 2010). The essential oil extracted from betel leaf contains phenol components, e.g., carvacrol, cineol, caryophyllene, eugenol, and chavicol (Agustin, 2005). The chavicol compound gives a distinctive aroma and has a bacterial killing power of 5 times greater than phenol (Agustin, 2005; Jirna et al., 2017).

Betle leaf essential oil also contains bioactive compounds that include tannins, saponins, flavonoids, essential oils, alkaloids, steroids, and polyphenols (Patil et al., 2015; Naufalin and Herastuti, 2013). Saponins are reported to exhibit anti-inflammatory activities that can reduce edema and skin inflammation (Navarro et al., 2001), hence feasible as antiseptics for mastitis treatment. Effa and Puetri (2015) reported that betel leaves extract with a concentration of $75 \%, 50 \%$, and $25 \%$ has the same ability as erythromycin at a dose of 19.95 $\mu \mathrm{g}, 18.75 \mu \mathrm{g}$, and $17.7 \mu \mathrm{g}$.

Kecombrang (Etlingera elatior) is a spice plant that has long been recognized for its medicinal value. According to Jaafar et al. (2007), the parts of kecombrang plant (leaves, stems, flowers, and rhizomes) made into essential oils may contain bioactive compounds. The highest essential oil is found in the leaves $(0.0735 \%)$, followed by flowers $(0.0334 \%)$, stems $(0.0029 \%)$, and rhizomes $(0.0021 \%)$. Findings reported by Hudaya et al. (2014) showed that kecombrang flower (Etlingera elatior) contains $20 \%$ water extract that can inhibit the growth of Staphylococcus aureus and Escherichia coli.

Additionally, turmeric (Curcuma longa L.) is a common plant for traditional medicine. Studies on pharmacological activity have shown that turmeric has antibacterial activities. Pangemanan et al. (2016) reported that the polar extract of turmeric rhizome at 5\%, 10\%, $20 \%$, and $40 \%$ can inhibit the growth of Staphylococcus aureus and Pseudomonas sp. Also, turmeric extract can inhibit the activity of Streptococcus agalactiae bacteria at a concentration of $12.5 \%, 25 \%$, and $50 \%$ (Poeloengan et al., 2006), and Escherichia coli bacteria at $50 \%$ and $100 \%$ (Rahmawati et al., 2014).

Accordingly, further investigation is needed to combine several herbal plant extracts to obtain better inhibitory power against mastitiscausing bacteria. Our study expects to find the best formulation for effective results in controlling mastitis in dairy cattle.

\section{Materials and Methods}

\section{Materials}

The lab apparatus for experiments were an autoclave, Petri dishes, measuring cups, hockey stick, incubator, inoculating loops and needles, Erlenmeyer flasks, laminar airflow, bunsen burners, micropipettes, blue tips, test tubes, test tube racks, refrigerator, analytical balance, calipers, and vortex.

The materials were chloramphenicol antibiotic, betel leaves extract, kecombrang flower extract, turmeric extract, aquadest, methanol, $0.9 \%$ physiological $\mathrm{NaCl}$, and Mueller Hinton Agar (MHA, OXOID). The extract was tested against Staphylococcus aureus, Streptococcus agalactiae, and Escherichia coli. 


\section{Procedures}

\section{Extraction of Betel Leaves, Kecombrang Flower, and Turmeric}

The extraction method used in this study was maceration (Harborne, 1998; Darwis, 2000). Betel leaves, kecombrang flower, and turmeric were washed, finely chopped, air-dried at room temperature, and pulverized. The powder was macerated in 98\% methanol solvent for $3 \times 24$ hours, filtered, then concentrated using a rotary evaporator at $400 \mathrm{C}$ and $100 \mathrm{mBar}$ pressure until the solvent stopped dripping. The extract concentrations of betel leaves, kecombrang flower, and turmeric following previous findings (Poeloengan et al., 2006; Herlina et al., 2013), namely $25 \%$ and $50 \%$ to harness inhibitory power against various types of bacteria that cause mastitis. The three extracts were dissolved in distilled water according to the concentration then mixed with the same volume ratio.

\section{Preparation of Mueller Hinton Agar Media (MHA)}

Exactly 19 grams of MHA were weighed and dissolved into the Erlenmeyer flask with distilled water until it gained $500 \mathrm{~mL}$ volume, then heated until homogeneous. The media were sterilized using an autoclave for 15 minutes at $121^{\circ} \mathrm{C}$, and then $25 \mathrm{~mL}$ of $\mathrm{MHA}$ was poured onto the Petri dishes and then let solid.

\section{Preparation of Bacterial Suspension}

Colony suspension of Staphylococcus aureus, Streptococcus agalactiae, and Escherichia coli was made by taking one dose pf colony from solid NA medium to the test tube containing $5 \mathrm{~mL}$ of physiological $\mathrm{NaCl}$. The turbidity of colony suspension was standardized with 0.5 McFarland standard (approximately $1.5 \times 108 \mathrm{CFU} / \mathrm{mL}$ ). The suspension should be used as an inoculum within 15 minutes.

\section{Antibacterial Testing by Using Well Diffusion Method}

The suspension of tested bacteria was inoculated in $0.1 \mathrm{~mL}$ MHA medium, flattened using a hockey stick, then let dry. A well was made using the tip of a sterile pipette, then poured in $40 \mu \mathrm{L}$ of the formulated extract and incubated for 18 hours at $37^{\circ} \mathrm{C}$. A clear zone was observed around the well, and the diameter was measured three times using a caliper with different positions, then the results were averaged.

\section{Research Design and Statistical Analysis}

The research was conducted experimentally in a Completely Randomized Design (CRD), consisting of 10 treatment combinations and four replicates. Treatment formulations in this study were:

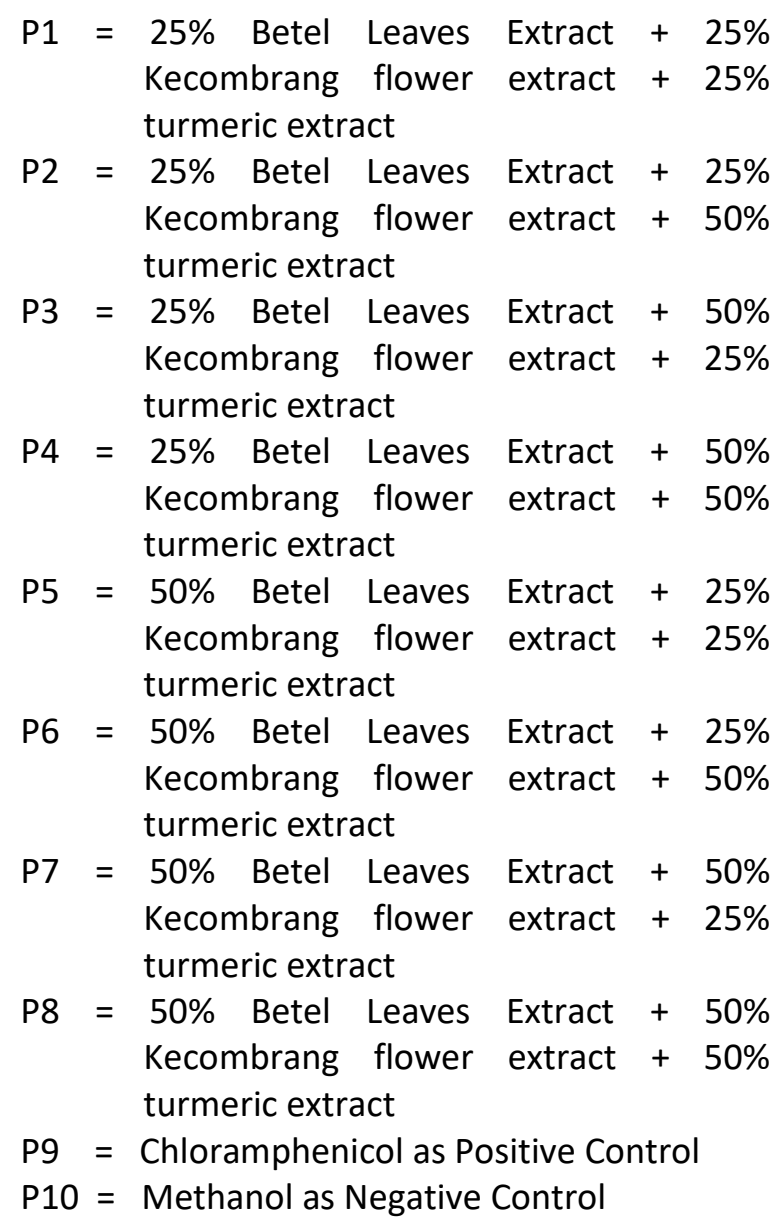


The data obtained were analyzed using analysis of variance (ANOVA), then further tested with Duncan's multiple range test. The best herbal antibacterial formulation was selected based on the inhibition zone diameter against bacteria.

\section{Results and Discussion}

\section{Inhibition of Herbal Antibacterial Formulations against Staphylococcus aureus}

The test results of herbal antibacterial formulations derived from the combination of betel leaves extract, kecombrang flower extract, and turmeric extract against Staphylococcus aureus are shown in Table 1. The results showed that the inhibition zone of various formulations indicated varying values, with the inhibitory power being in a strong category and very strong for positive control. Davis and Stout (1971) categorize the strength of antibacterial power into four, namely weak $(<5 \mathrm{~mm})$, moderate $(5-10 \mathrm{~mm})$, strong $(10-20 \mathrm{~mm})$, and very strong $(>20 \mathrm{~mm})$.

The result of variance analysis showed that the treatment of herbal antibacterial formulations significantly $(p<0.05)$ affected the inhibition zone of Staphylococcus aureus bacteria. Duncan's multiple range test was carried out to determine different effects among treatments. While the smallest diameter of inhibition zone was observed in P1 (25\% betel leaves extract $+25 \%$ kecombrang flower extract $+25 \%$ turmeric extract) and P3 (25\% betel leaves extract $+50 \%$ kecombrang flower extract $+25 \%$ turmeric extract), the biggest diameter was in $\mathrm{P} 9$ treatment (chloramphenicol as positive control). Methanol as negative control did not show any inhibition zone. Extracts with high concentrations produced a larger diameter of the inhibition zone. P8 treatment $(50 \%$ betel leaves extract $+50 \%$ kecombrang flower extract $+50 \%$ turmeric extract) had the biggest inhibition zone diameter because the higher percentage of the active substance content, the more opportunities to inhibit the growth of Staphylococcus aureus.

Staphylococcus aureus is a Gram-positive bacterium that is the most dominant cause of subclinical mastitis leading to health problems in humans because more than half of the strains isolated in milk from infected glands have enterotoxin genes (less than 10000 CFU / $\mathrm{mL}$ ) and can cause staphylococcal poisoning in fermented milk products (Le Marechal et al., 2011). Staphylococcus aureus can become resistant to antibiotics by producing a number of virulence factors, including exotoxins and cell membrane proteins (Fitzgerald et al., 2001).

Table 1. Inhibition Zone of Herbal Antibacterial Formulations against Staphylococcus aureus, Streptococcus agalactiae, and Escherichia coli

\begin{tabular}{lcccc}
\hline Formulation & \multicolumn{2}{c}{ Average of Inhibition Zone Diameter $(\mathrm{mm})$} & Power of \\
\cline { 2 - 4 } Treatments & S. aureus & S. agalactiae & E. coli & Inhibition \\
\hline P1 & $10.6 \pm 0.34^{\mathrm{b}}$ & $11.2 \pm 0.17^{\mathrm{bc}}$ & $11.2 \pm 0.29^{\mathrm{b}}$ & Strong \\
P2 & $11.4 \pm 0.05^{\mathrm{d}}$ & $11.4 \pm 0.33^{\mathrm{bc}}$ & $11.7 \pm 0.13^{\mathrm{bc}}$ & Strong \\
P3 & $10.6 \pm 0.15^{\mathrm{b}}$ & $11.8 \pm 0.52^{\mathrm{bc}}$ & $11.9 \pm 0.10^{\text {cde }}$ & Strong \\
P4 & $10.8 \pm 0.16^{\mathrm{bc}}$ & $10.9 \pm 0.38^{\mathrm{bc}}$ & $11.7 \pm 0.21^{\mathrm{bc}}$ & Strong \\
P5 & $11.1 \pm 0.08^{\mathrm{cd}}$ & $10.8 \pm 0.42^{\mathrm{b}}$ & $11.8 \pm 0.13^{\mathrm{cd}}$ & Strong \\
P6 & $11.2 \pm 0.28^{\mathrm{cd}}$ & $11.2 \pm 0.66^{\mathrm{bc}}$ & $12.1 \pm 0.08^{\text {cde }}$ & Strong \\
P7 & $11.4 \pm 0.38^{\mathrm{d}}$ & $11.8 \pm 0.54^{\mathrm{c}}$ & $12.3 \pm 0.13^{\mathrm{de}}$ & Strong \\
P8 & $12.2 \pm 0.38^{\mathrm{e}}$ & $12.7 \pm 0.74^{\mathrm{d}}$ & $12.4 \pm 0.41^{\mathrm{e}}$ & Strong \\
P9 (+) & $38.1 \pm 0.49^{\mathrm{f}}$ & $38.5 \pm 1.20^{\mathrm{e}}$ & $39.9 \pm 0.82^{\mathrm{f}}$ & Very Strong \\
P10 (-) & $0 \pm 0^{\mathrm{a}}$ & $0 \pm 0^{\mathrm{a}}$ & $0 \pm 0^{\mathrm{a}}$ & No Inhibition \\
\hline
\end{tabular}

Positive control $(+)=$ chloramphenicol. Negative control $(-)=$ methanol 
Betel leaves, kecombrang flower, and turmeric have been widely researched and proven to have pharmacological activities, one of which is antibacterial. Betel leaf contains essential oils with phenolic compounds that can inhibit microbial growth. Essential oils inhibit growth or kill bacteria by disrupting the process of forming membranes and/or cell walls so that the membrane or cell wall is not formed completely (Ajizah, 2004). Poeloengan et al. (2006) showed that the essential oils contained in betel leaves (25\% and 50\%) could inhibit Staphylococcus aureus with inhibition zone diameters of $8 \mathrm{~mm}$ and $10.3 \mathrm{~mm}$. Similarly, kecombrang flower also contains essential oils as well as chemical compounds such as alkaloids, flavonoids, steroids, polyphenols, and saponins (Naufalin and Herastuti, 2013). Hudaya et al. (2014) reported that the water extract of kecombrang flower (Etlingera elatior) at a concentration of $20 \%$ was able to inhibit the growth of Staphylococcus aureus with an inhibition zone diameter of $8.67 \mathrm{~mm}$. Meanwhile, turmeric contains curcumin and essential oils which could inhibit the growth of Staphylococcus aureus (Ramadhani et al., 2017). The antibacterial agent mechanism of curcumin is similar to other phenolic compounds, namely inhibiting bacterial metabolism by damaging the cytoplasmic membrane and denaturing cell proteins which cause nutrient leakage from cells so that bacterial cells die or are stunted in growth (Madigan and Martinko, 2005). The research result of Muadifah et al. (2019) showed that turmeric rhizome extract at a concentration of $45 \%$ has strong bacterial activity against Staphylococcus aureus with an inhibition zone diameter of $11 \mathrm{~mm}$.

\section{Inhibition of Herbal Antibacterial Formulations against Streptococcus agalactiae}

The test results of herbal antibacterial formulations against Streptococcus agalactiae in Table 1 showed that the inhibition zone of various formulations indicated varying values, with the inhibitory power being a strong category. The result of variance analysis showed that the treatment of herbal antibacterial formulations had a significant effect $(p<0.05)$ on the inhibition zone of Streptococcus agalactiae bacteria. The results of Duncan's multiple range test showed that the smallest inhibition zone diameter was obtained by P5 treatment (50\% betel leaves extract $+25 \%$ kecombrang flower extract $+25 \%$ turmeric extract), the largest inhibition zone diameter was in P9 treatment (chloramphenicol as positive control), and methanol as negative control did not show any inhibition zone. P8 treatment $(50 \%$ betel leaves extract $+50 \%$ kecombrang flower extract $+50 \%$ turmeric extract) showed the largest inhibition zone diameter because the greater the combined extract concentration, the greater the inhibition zone diameter formed.

Streptococcus agalactiae is a Gram-positive bacterium from species of Streptococcus which is the main cause of subclinical mastitis disease. According to Wibawan and Laemmler (1990), Streptococcus agalactiae contains polysaccharide antigens which are dominantly composed of sialic acid and their cell walls have protein antigens with $X$-serotype as an immunogenic virulence factor. Streptococcus agalactiae has a capsule composed of sialic acid and other carbohydrate compounds that form an oligosaccharide structure. This capsule is one of the virulent factors of Streptococcus agalactiae that plays a role in preventing phagocytosis, attacks from anti-inflammatory cells, and bacteria-killing, as well as determining survival. Therefore, the selected antibacterial should be sufficiently toxic to inhibit the bacterial cell wall, enzyme action, permeability of bacterial cell walls, and the synthesis of nucleic acids and proteins.

Betel leaves, kecombrang flower, and turmeric have been shown to inhibit the growth of Streptococcus agalactiae. The research results of Poeloengan et al. (2006) showed that 
ethanol extract of betel leaves at a concentration of $12.5 \%, 25 \%$, and $50 \%$ could inhibit the growth of Streptococcus agalactiae with inhibition zone diameters of $6.3 \mathrm{~mm}, 8$ $\mathrm{mm}$, and $10.3 \mathrm{~mm}$, respectively. The greater concentration of ethanol extract and essential oil of betel leaves, the larger the inhibition zone. Naufalin et al. (2005) reported that kecombrang flowers had an average essential oils content of $17 \%$. The phytochemical components of the kecombrang flower ethanol extract are phenolics, triterpenoids, flavonoids, alkaloids, and glycosides which can inhibit the growth of Streptococcus agalactiae by damaging the metabolism system of bacterial cells. Furthermore, Lawhavinit et al. (2010) reported that the ethanol extract of turmeric showed antibacterial effect against 13 bacteria including Streptococcus agalactiae with an inhibition zone diameter of $22 \mathrm{~mm}$.

\section{Inhibition of Herbal Antibacterial Formulations against Escherichia coli}

The test results of herbal antibacterial formulations against Escherichia coli in Table 1 show that the inhibition zone of various formulations indicated varying values within the strong category. The result of variance analysis showed that the treatment of herbal antibacterial formulations significantly affected $(p<0.05)$ the inhibition zone of Escherichia coli bacteria. The results of Duncan's multiple range test showed that the smallest inhibition zone diameter was obtained by P1 treatment (25\% betel leaves extract $+25 \%$ kecombrang flower extract $+25 \%$ turmeric extract), the largest inhibition zone diameter was in P9 treatment (chloramphenicol as positive control), while methanol as negative control did not show any inhibition zone. The formulation with the highest concentration was P8 treatment $(50 \%$ betel leaves extract $+50 \%$ kecombrang flower extract $+50 \%$ turmeric extract), which showed the largest inhibition zone diameter.
Coliform bacteria often cause clinical mastitis in dairy cattle. The most common species, isolated in more than $80 \%$ of coliform mastitis cases, is Escherichia coli (Bradley and Green, 2001) which is from the Enterobacteriaceae family and is described as a facultatively anaerobic, Gram-negative, nonspore-forming, rod-shaped bacteria (PHAC, 2020). These bacteria could be found in the environment (such as water, soil, air, and dust), pieces of equipment during production, and workers. Escherichia coli is a feasible indicator of antimicrobial resistance (Kusumaningsih and Ariyanti, 2013; Loncaric et al., 2013). Broadspectrum antimicrobials are usually utilized for mastitis treatment by Escherichia coli (Erskine et al., 2003).

Rambe et al. (2019) showed that the concentrations of $15 \%, 30 \%, 45 \%$, and $60 \%$ of green betel leaves extract can inhibit the growth of Escherichia coli with inhibition zone diameters of $9.2 \mathrm{~mm}, 10 \mathrm{~mm}, 12.2 \mathrm{~mm}$, and $15.6 \mathrm{~mm}$, respectively. Also, Naufalin et al. (2005) reported that the ethanol extract of kecombrang flower exhibits activities against Bacillus cereus, Pseudomonas aeruginosa, Escherichia coli, Salmonella typhimurium, Listeria monocytogenes, and Aeromonas hydrophila with inhibition zone diameters ranging from $11.0-15.4 \mathrm{~mm}$ at a concentration of $30 \mathrm{mg} / \mathrm{ml}$. Rahmawati et al. (2014) reported that turmeric extract had an inhibition zone diameter against Escherichia coli of $5.64 \mathrm{~mm}$ with a minimum concentration of $50 \%$.

Based on the research data, we can conclude that the largest inhibition was obtained by the P8 formulation treatment (Figure 1); therefore, the greater concentration of extracts combined, the larger the inhibition. It is because more active substances enable more opportunity to inhibit the growth of Staphylococcus aureus, Streptococcus agalactiae, and Escherichia coli bacteria. 

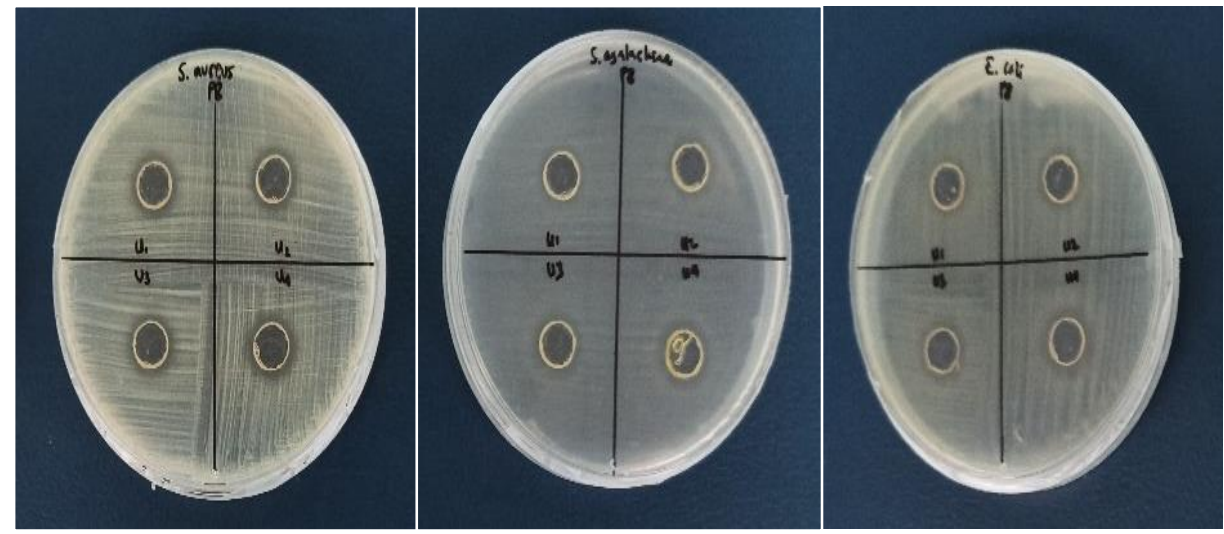

Figure 1. Antibacterial Activity of P8 Formulation

The inhibitory power of the herbal antibacterial agent in P8 formulation showed a strong value, although it is below chloramphenicol which was very strong. The percentage of inhibitory power of the P8 formulation compared to chloramphenicol was $32 \%$ against Staphylococcus aureus, 33\% against Streptococcus agalactiae, and $31 \%$ against Escherichia coli bacteria. Jenie and Kuswanto (1994) stated that the effectiveness of antibacterial substances to inhibit growth depends on characteristics of bacteria, concentration, and duration of contact. According to Volk and Wheeler (1993), higher levels of bioactive compounds are generally bactericidal (killing microbes), whereas lower levels are usually only bacteriostatic (inhibiting growth, not killing microbes).

The positive control used in this study was chloramphenicol, which is a broad spectrum of antibiotics that can inhibit gram-positive, gramnegative aerobic, and anaerobic bacteria (Mycek et al., 2001). It works by inhibiting protein synthesis and preventing the end of the aminoacyl t-RNA from joining peptidyl transferase (the enzyme that links the amino acid to the peptide chain during protein synthesis) (Olson, 2004), thus immediately halting the bacterial protein synthesis. The inhibition zone produced by the herbal antibacterial formulation in this study was not comparable to the control because the active ingredients contained in chloramphenicol were pure. The content of the active compounds in the herbal antibacterial formulations tested was not pure, so the inhibition against bacteria was not as effective as chloramphenicol. It is necessary to select and characterize the antibacterial compounds contained in these materials to measure the active substance content. The negative control used in this study was methanol and did not show inhibition zones because methanol cannot inhibit the bacteria.

\section{Conclusions}

The best herbal antibacterial formulation was a combination of $50 \%$ betel leaves extract, $50 \%$ kecombrang flower extract, and 50\% turmeric extract.

\section{Acknowledgment}

The authors express their gratitude to the Directorate of Research and Community Service, Ministry of Research and Technology / National Research and Innovation Agency (RISTEK-BRIN) of Republic Indonesia for funding this research (Beginner Lecturer Research Scheme, funding year 2020).

\section{References}

Agustin, D. 2005. The comparison of the antibacterial effect of irrigation solutions hydrogen peroxyde $3 \%$ and piper betle folium infusum 20\% to bacterial mix. Dental Journal. 38(1):45-47. 
Ajizah, A. 2004. Sensitivitas Salmonella typhimurium terhadap Ekstrak Daun Psidium guajava L. Bioscientiae. 1(1):31-38.

Beyene, T. 2016. Veterinary drug residues in foodanimal products: its risk factors and potential effects on public health. Journal of Veterinary \& Science Technology. 7(1):1-7.

Bradley, AJ and MJ Green. 2001. Adaptation of Escherichia coli to the bovine mammary gland. Journal of Clinical Microbiology. 39(5):18451849.

Caburian, $A B$ and MO Osi. 2010. Characterization and evaluation of antimicrobial activity of the essential oil from the leaves of Piper betle L. EInternational Scientific Research Journal. 2(1):213.

Darwis, D. 2000. Teknik Dasar Laboratorium dalam Penelitian Senyawa Bahan Alam Hayati. Paper at Workshop Pengembangan Sumberdaya Manusia dalam Bidang Kimia Organik Bahan Alam Hayati. Faculty of Math and Science, Andalas University, Padang.

Davis, WW and TR Stout. 1971. Disc plate method of microbiological antibiotic assay. Applied Microbiology. 22 (4):659-665.

Effa and NR Puetri. 2015. Pengaruh Pemberian Ekstrak Daun Sirih (Piper betle L.) terhadap Pertumbuhan Staphylococcus aureus Isolat dari Penderita Faringitis. SEL. 2(2):57-65.

Erskine, RJ, S Wagner and FJ DeGraves. 2003. Mastitis therapy and pharmacology. Veterinary Clinics of North America: Food Animal Practice. 19(1):109-138.

Fitzgerald, JR, SR Monday, TJ Foster, GA Bohach, PJ Hartigan, WJ Meaney, and CJ Smyth. 2001. Characterization of a putative pathogenicity island from bovine Staphylococcus aureus encoding multiple superantigens. Journal of Bacteriology. 183(1):63-70.

Harborne, JB. 1998. Phytochemical Methods. A Guide to Modern Techniques of Plant Analysis. 3rd ed., Chapman \& Hall, London.

Herlina, N, ND Yanthi, M Poeloengan, B Tappa. 2013. Daya Hambat Formulasi Antibakteri Asal Mikroorganisme dan Tanaman terhadap Streptococcus agalactiae Penyebab Mastitis Pada Sapi Perah. In: Proceeding of Seminar Nasional Peternakan dan Forum Komunikasi Peternakan. Bogor, September 18-19, 2013. Pp:577-587.

Hudaya, A, N Radiastuti, D Sukandar and I Djajanegara. 2014. Uji Aktivitas Antibakteri Ekstak Air Bunga Kecombrang terhadap Bakteri E. coli dan S. aureus sebagai Bahan Pangan Fungsional. Alkauniyah Jurnal Biologi. 7(1):9-15.

Jaafar, FM, CP Osman, NH Ismail, and K Awang. 2007. Analysis of essential oils of leaves, stems, flowers and rhizomes of Etlingera elatior (Jack) R.
M. Smith. The Malaysian Journal of Analytical Sciences. 11(1):269-273.

Jenie, BSL and Kuswanto. 1994. Aktivitas antimikroba dari pigmen angkak yang diproduksi oleh Monasnrs purpuracs terhadap beberapa mikroba patogen dan perusak makanan. In: Proceeding of Pertemuan Ilmiah Tahunan Permi. Bogor, Desember 10, 1994. Pp:53-62.

Jirna, IN, N Mastra, LA Wilan, I Karta, and Burhannudin. 2017. Potency of lime (Citrus aurantifolia) as bio-disinfectant of Staphylococcus aureus. Dama International Journal of Researchers (DIJR). 2(1):63-67.

Kusumaningsih, A and T Ariyanti. 2013. Pathogenic bacteria contamination in fresh dairy milk and its resistance to antibiotic. Berita Biologi. 12(1):9-17.

Lawhavinit, O, N Kongkathip, and B Kongkathip. 2010. Antimicrobial activity of curcuminoids from Curcuma longa $L$. on pathogenic bacteria of shrimp and chicken. Kasetsart Journal-Natural Science. 44(3):364-371.

Le Marechal, C, R Thiery, E Vautor, and Y Le Loir. 2011. Mastitis Impact on Technological Properties of Milk and Quality of Milk Products-a Review. Dairy Science \& Technology. 91:247-282.

Loncaric, I, GL Stalder, K Mehinagic, R Rosengarten, F Hoelzl, F Knauer, and C Walzer. 2013. Comparison of ESBL-And AmpC producing Enterobacteriaceae and Methicillin-Resistant Staphylococcus aureus (MRSA) Isolated from Migratory and Resident Population of Rooks (Corvus frugigelgus) in Austria. PLOS ONE. 8(12): 1-11.

Madigan, MT and JM Martinko. 2005. Brock Microbiology of Microorganisms. 11th Ed., Prentice Hall Inc, New Jersey.

Muadifah, A, AE Putri, and N Latifah. 2019. Aktivitas Gel Ekstrak Rimpang Kunyit (Curcuma domestica Val) terhadap Bakteri Staphylococcus aureus. Jurnal Sainhealth. 3(1):45-54.

Mycek, MJ, RA Harvey, PC Champe. 2001. Pharmacology. 2nd ed., Widya Medika, Jakarta.

Naufalin, R and SR Herastuti. 2013. Microcapsule application of kecombrang flower extract: effects of concentration, types of fraction, $\mathrm{pH}$ of medium, and $\mathrm{NaCl}$ on microbiological properties of minced beef. Animal Production. 15(1):8-14.

Naufalin, R, BSL Jenie, F Kusnandar, M Sudarwamto, and $H$ Rukmini. 2005. Antibacterial activity of kecombrang flower extract toward pathogenic and food spoilage bacteria. Jurnal Teknologi dan Industri Pangan. 16(2):119-125.

Navarro, P, RM Giner, MC Recio, S Máñez, M CerdáNicolás, JL Ríos. 2001. In vivo anti-inflammatory activity of saponins from Bupleurum rotundifolium. Life Sciences. 68(10): 1199-1206. 
Olson, J. 2004. Clinical Pharmacology: Made Ridiculously Simple. 1st ed., EGC, Jakarta. 203 Pages.

Pangemanan, A, Fatimawali, dan F Budiarso. 2016. Uji Daya Hambat Ekstrak Rimpang Kunyit (Curcuma longa) terhadap Pertumbuhan Bakteri Staphylococcus aureus dan Pseudomonas sp. Jurnal e-Biomedik (eBm). 4(1):81-85.

Pasca, C, L Marghitas, D Dezmirean, O Bobis, V Bonta, F Chirila, I Matei, and N Fit. 2017. Medicinal plants based products tested on pathogens isolated from mastitis milk. Molecules. 22(9):1-16.

Patil, RS, PM Harale, KV Shivangekar, PP Kumbhar, and RR Desai. 2015. Phytochemical potential and in vitro antimicrobial activity of Piper betle Linn. leaf extracts. Journal of Chemical and Pharmaceutical Research. 7(5):1095-1101.

PHAC (Public Health Agency of Canada). 2020. Guidelines for Canadian Drinking Water Quality: Guideline Technical Document-Escherichia coli. https://www.canada.ca/en/health canada/servic es/publications/healthy living/guidelines canadia $\mathrm{n}$ drinking water quality guideline technical docu ment-escherichia-coli.html (accessed: December 04, 2020).

Pisestyani, H, E Sudarnika, R Ramadhanita, AZ Ilyas, A Wicaksono, C Basri, AB Nugraha, and MB Sudarwanto. 2017. Teat dipping treatment after milking process to the presence of pathogenic bacteria, Staphylococcus aureus, Streptococcus agalactiae, and E. coli in dairy cattle with positive subclinical mastitis at Kunak Bogor. Jurnal Sain Veteriner. 35(1):63-70.

Poeloengan, M, I Komala, SM Noor, Andriani, and SRP Rianti. 2006. Activity water extract, of essential oil and ethanol extraction of piper bittle leaves against bacteria isolated from sub clinical mastitis cattle. Seminar Nasional Teknologi Peternakan dan Veteriner 2006. Pp:250-255.
Rahmawati, N, E Sudjarwo, and E Widodo. 2014. Uji Aktivitas Antibakteri Ekstrak Herbal terhadap Bakteri Escherichia coli. Jurnal IImu-IImu Peternakan. 24(3):24-31.

Ramadhani, P, Erly, and Asterina. 2017. Hambat Ekstrak Etanol Rimpang Kunyit (Curcuma domestika V.) terhadap Pertumbuhan Bakteri Staphylococcus aureus Secara In Vitro. Jurnal Kesehatan Andalas. 6(3):590-595.

Rambe, DR, Allaily, and $\mathrm{Cl}$ Novita. 2019. Inhibitory analysis of green betel leaf extract (Piper betle L.) against mastitis causing microorganism. Jurnal Ilmiah Mahasiswa Pertanian. 4(2):230-236.

Sachi, S, J Ferdous, MH Sikder, and SMAK Hussani. 2019. Antibiotic residues in milk: past, present, and future. Journal of Advanced Veterinary and Animal Research. 6(3):315-332.

Seegers, H, C Fourichon, and F Beaudeau. 2003. Production effects related to mastitis and mastitis economics in dairy cattle herds. Veterinary Research, Biomed Central. 34(5):475491.

Sutarti, E, S Budiharta, and B Sumiarto. 2003. Prevalence and factors associated with mastitis in smallholder dairy cows in District of Semarang, Central Java. Jurnal Sain Veteriner. 21(1):43-49.

Syamsi, AN, M Pratiwi and AP Nugroho. 2019. Inhibition Activity of Garlic (Allium sativum) Skin Extract on Mastitis Causing Microorganism. Animal Production, 21(1):38-42.

Volk, WA and MF Wheeler. 1993. Basic Microbiology. 5th ed., Erlangga, Jakarta.

Wahyuni, AETH, IWT Wibawan, FH Pasaribu, and BP Priosoeryanto. 2006. Distribution of serotype of Streptococcus agalactiae caused subclinical mastitis on dairy cattle in East Java, Center Java and West Java. Jurnal Veteriner. 7(1):1-8.

Wibawan, IWT and $\mathrm{CH}$ Leammler. 1990. Properties of group B Streptococci with Protein Surface Antigens $X$ and $R$. Journal of Clinical Microbiology. 28 (12): 2834-2836. 